\title{
APPLICATION OF ALGAE IN ACTIVE BIOMONITORING OF THE SELECTED HOLDING RESERVOIRS IN SWIETOKRZYSKIE PROVINCE
}

\author{
ZASTOSOWANIE GLONÓW W BIOMONITORINGU AKTYWNYM \\ WYBRANYCH ZBIORNIKÓW RETENCYJNYCH \\ WOJEWÓDZTWA ŚWIĘTOKRZYSKIEGO
}

\begin{abstract}
During the years 2014-2015, biomonitoring studies were carried out at three holding reservoirs located in Swietokrzyskie Province (central Poland): Kielce artificial lake, Chancza reservoir and Sielpia reservoir. In sea water algae Palmaria palmata (Linnaeus) Weber \& Mohr, exposed in the analysed waters, the increases of concentrations were determined by the atomic absorption spectrometry method (AAS), of the following: Mn, Fe, $\mathrm{Cu}, \mathrm{Zn}, \mathrm{Cd}$ and $\mathrm{Pb}$. Conductivity and $\mathrm{pH}$ were also determined in the reservoirs waters. The differences between the increases of heavy metal concentrations in the samples of algae found along the coastline were indicated; they result from different distances from the pollution sources, such as resorts, communication routes and industrial plants.
\end{abstract}

Keywords: sea algae, Palmaria palmata (Linnaeus) Weber \& Mohr, heavy metals, biomonitoring, retention reservoirs, atomic absorption spectrometry

\section{Introduction}

The algae [1, 2], which have good sorption characteristics [3-5] are most often used in active biomonitoring of surface waters.

Algae are thalloid plants. Apart from eukaryotic organisms (among others Palmaria palmata and Spirogyra sp.), there are also those with prokaryotic cell structure. This group has a diverse morphological structure of thallus and various shapes [6-8].

The studies carried out with the use of sea and fresh water algae confirm their practical application not only in biomonitoring of surface waters pollution [9-16] but also waters phytoremediation [17] and as biosorbents in the effluent treatment process [18].

\footnotetext{
${ }^{1}$ Chair of Biotechnology and Molecular Biology, Opole University, ul. kard. B. Kominka 6, 45-032 Opole, Poland, phone +48 7740160 42, email: mrajfur@o2.pl

${ }^{2}$ Chair of Environment Shaping and Protection, Jan Kochanowski University in Kielce, ul. Świętokrzyska 15, 25-406 Kielce, Poland

${ }^{3}$ Department of Physics, University of Hradec Králové, Rokitanského 62, 50003 Hradec Králové, Czech Republic *Corresponding author: mrajfur@o2.pl
} 
Some instrumental methods of water chemical composition, eg atomic absorption spectrometry (AAS), require concentrating of water samples in order to determine the trace quantities of heavy metals. Algae can be used for that purpose due to very good sorption characteristics. After mineralisation of algae samples, the solutions contain much higher concentrations of metals, compared to such concentrations in water [3]. Determining the correlation between concentrations of analytes in algae and water can be used to prepare a simple method for determination of heavy metals concentration in surface waters, on the basis of the chemical analysis of the algae thallus composition.

The objective of the studies was to apply active biomonitoring to determine the distribution of bioaccessible forms of heavy metals: $\mathrm{Mn}, \mathrm{Fe}, \mathrm{Cu}, \mathrm{Zn}, \mathrm{Cd}$ and $\mathrm{Pb}$ along the coastline of the retention reservoirs: Kielce artificial lake, Chancza and Sielpia reservoirs and demonstrate heterogeneity of the distribution of analytes concentrations in the studied reservoirs resulting, among others, from the distance from pollution sources. The sea algae Palmaria palmata were used in the study and exposed in the studied reservoirs.

\section{Characteristics of the research field}

The Kielce reservoir was created within Kielce municipal border, by closing the Silnica river valley with a weir, at its 8 th kilometre. The areas in the reservoir vicinity have both recreation and economic function. The artificial lake water is supplied from a stream, which also collects communal waste from Maslow - a locality near Kielce. The amounts and diversity of both organic and non-organic compounds supplied to the reservoirs causes a considerable pollution level of its waters [19].

The Chancza reservoir is located on the Czarna Staszowska river, near the town of Staszow, in the south-eastern part of Swietokrzyskie province. The area belongs to the Nida Basin macroregion and Szydlow Upland and Orlowski Range mezoregions. The Czarna Staszowska river is a left tributary of the Vistula and its waters, as well as the waters of the Chancza reservoir, are in category II, as far as physical and chemical elements are concerned [20].

The Sielpia reservoir is an artificial lake with 60 hectares of surface, located in the north-western part of Swietokrzyskie province, between Kielce (approximately $35 \mathrm{~km}$ ) and Konskie (approximately $10 \mathrm{~km}$ ), in the locality of Sielpia Wielka. The Czarna Maleniecka river influences cleanliness of the reservoir waters; the river's chemical condition in 2014 was estimated as good (class II as far as physical and chemical elements are concerned). Rain waters from numerous resorts and woodlands surrounding feed its waters [20].

The bodies of water included in biomonitoring studies abound in numerous flora and rare fauna species. These reservoirs are the recreation spots for the inhabitants of Swietokrzyskie province [21].

\section{Materials and methods}

Palmaria palmata (Linnaeus) Weber \& Mohr sea algae purchased from the company BogutynMłyn from Radzyn Podlaski (PL) were used for the research. The sea algae were purchased dried. In order to remove the salts released in consequence of destruction of cell membranes, the algae were rinsed with demineralised water and dried for 24 hours at the temperature of $323 \mathrm{~K}$. The algae prepared in this way were stored for further analyses. 
The concentrations of metals naturally accumulated in the dry mass (d.m.) of Palmaria palmata amounted to the following: $c_{M n, 0}=615 \pm 13 \mathrm{mg} / \mathrm{kg}$ d.m.; $c_{F e, 0}=966 \pm 18 \mathrm{mg} / \mathrm{kg}$ d.m.; $c_{C u, 0}=4,32 \pm 0.08 \mathrm{mg} / \mathrm{kg} \mathrm{d.m}$.; $c_{Z n, 0}=32,7 \pm 0.1 \mathrm{mg} / \mathrm{kg}$ d.m.; $c_{C d, 0}=<0,81 \mathrm{mg} / \mathrm{kg}$ d.m.; $c_{P b, 0}=<4,38 \mathrm{mg} / \mathrm{kg} \mathrm{d} . \mathrm{m}$.

The representative (averaged) algae samples with the mass of $1 \mathrm{~g} \mathrm{~d} . \mathrm{m}$. were placed in perforated polyethylene containers of capacity $c a 15 \mathrm{~cm}^{3}$. Prior to exposition, algae were immersed for 15 minutes in demineralised water, in order to activate sorption centres. Next, samples were exposed in waters of the studied reservoirs for 50 minutes. Biomonitoring of the Chancza reservoir included also the waters feeding the reservoirs, form the rivers: Czarna Staszowska and Lagowica. The samples were immersed in water approximately 1 meter from the shore, in the littoral zone. The study included five repetitions. Simultaneously, water samples were taken in the defined measuring spots, in order to determine physical and chemical parameters ( $\mathrm{pH}$ and conductivity).

Figure 1 presents the map of measuring spots locations.

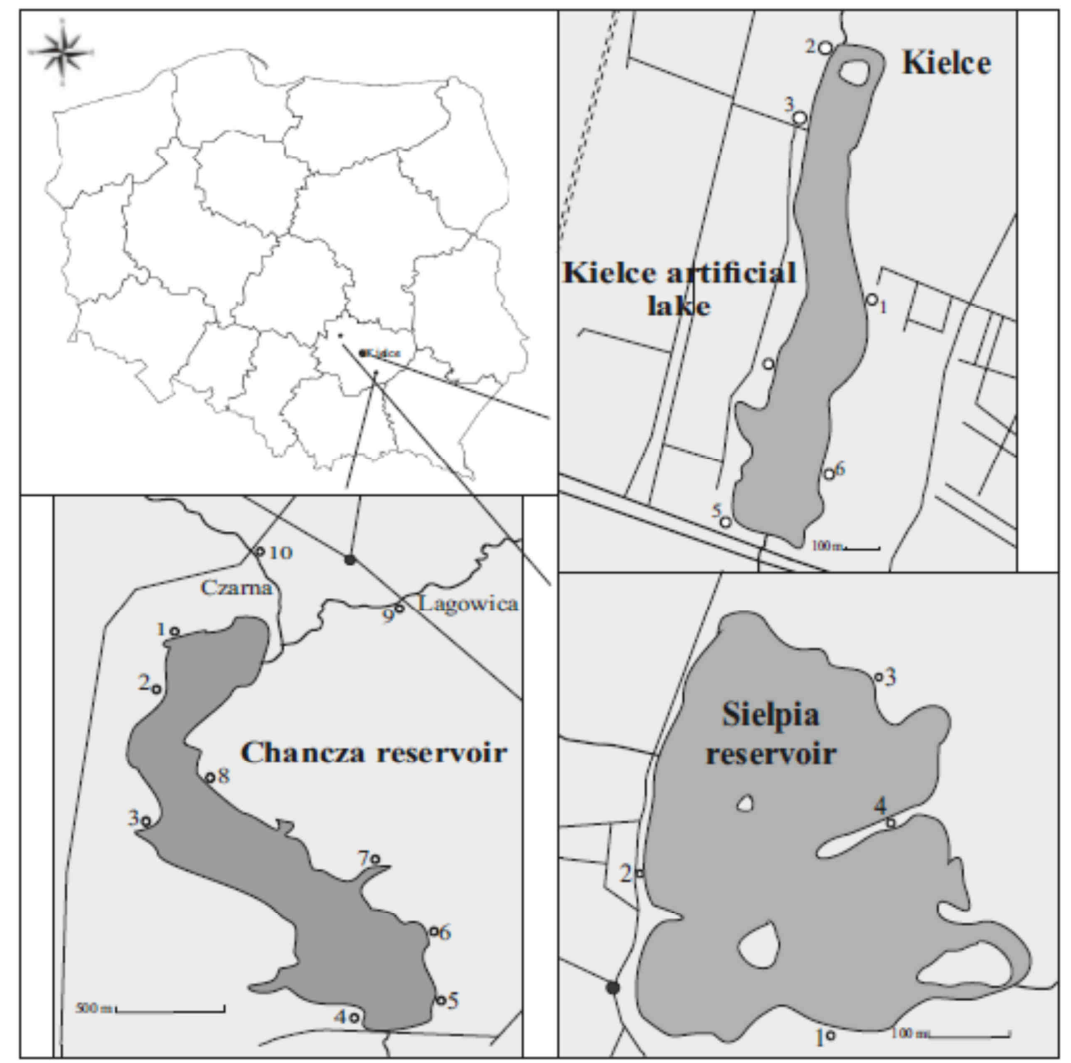

Fig. 1. Measuring spots locations

After exposition, algae samples were rinsed with demineralised water and dried at the temperature of $323 \mathrm{~K}$. The algae samples (dry mass each of them was $0.400 \pm 0.001 \mathrm{~g}$ ) were mineralised in the mixture of nitric $(\mathrm{V})$ acid and hydrochloric acid $\left(\mathrm{HNO}_{3} 65 \%: \mathrm{HCl}\right.$ 
$37 \%=1: 3$ ) using a Speedwave Four made by Berghof, DE microwave oven. The mineralization process temperature was $180^{\circ} \mathrm{C}$. MERCK company reagents were used to prepare solutions. Heavy metals $(\mathrm{Mn}, \mathrm{Fe}, \mathrm{Cu}, \mathrm{Zn}, \mathrm{Cd}$ and $\mathrm{Pb}$ ) in mineralised algae samples were determined by atomic absorption spectrometry method (AAS), using the equipment iCE 3000 made by Thermo Electron Corporation (USA).

The conductivity and $\mathrm{pH}$ of the water, in which algae were immersed, were measured with the equipment made by Elmetron Sp.j. from Zabrze (PL): $\mathrm{pH}$ meter CP 401, which absolute measurement error was $\Delta \mathrm{pH}=0.02$ and $\Delta \kappa=0.1 \mu \mathrm{S} / \mathrm{cm}$, respectively.

\section{Quality and quality assurance}

Table 1 presents the limits of detection and the limits of quantification of heavy metals for the spectrometer iCE 3500 [22]. Calibration of spectrometer was performed with a standard solution from ANALYTIKA Ltd. (Czech Republic). The values of the highest concentrations of the models used for calibration $\left(2 \mathrm{mg} / \mathrm{dm}^{3}\right.$ for $\mathrm{Cd}, 5 \mathrm{mg} / \mathrm{dm}^{3}$ for $\mathrm{Cu}, \mathrm{Zn}$, $\mathrm{Pb}, 7.5 \mathrm{mg} / \mathrm{dm}^{3}$ for $\mathrm{Mn}$ and $10 \mathrm{mg} / \mathrm{dm}^{3}$ for $\mathrm{Fe}$ ) ware approved as linear limits of the signal dependence on the concentration.

Table 1

The instrumental detection limits $(I D L)$ and instrumental quantification limits $(I Q L)$ for the spectrometer iCE $3500\left[\mathrm{mg} / \mathrm{dm}^{3}\right]$ [22]

\begin{tabular}{|c|c|c|}
\hline Metal & IDL & IQL \\
\hline $\mathrm{Mn}$ & 0.0016 & 0.020 \\
\hline $\mathrm{Fe}$ & 0.0043 & 0.050 \\
\hline $\mathrm{Cu}$ & 0.0045 & 0.033 \\
\hline $\mathrm{Zn}$ & 0.0033 & 0.010 \\
\hline $\mathrm{Cd}$ & 0.0028 & 0.013 \\
\hline $\mathrm{Pb}$ & 0.0130 & 0.070 \\
\hline
\end{tabular}

Table 2

Comparison of measured and certified concentrations in BCR-414 plankton and in BCR-482 lichen

\begin{tabular}{|c|c|c|c|c|c|}
\hline \multirow{3}{*}{ Metal } & \multicolumn{2}{|c|}{ BCR-414 plankton } & \multicolumn{2}{|c|}{ AAS } & \multirow{2}{*}{ Dev. ${ }^{* *}$} \\
\hline & Concentration & \pm Uncertainty & Average & $\pm S D^{*}$ & \\
\hline & \multicolumn{4}{|c|}{ [mg/kg d.m.] } & {$[\%]$} \\
\hline $\mathrm{Mn}$ & 299 & 12 & 284 & 13 & -5.0 \\
\hline $\mathrm{Fe}$ & 1.85 & 0.19 & 1.79 & 0.20 & -3.2 \\
\hline $\mathrm{Cu}$ & 29.5 & 1.3 & 28.4 & 1.6 & -3.7 \\
\hline $\mathrm{Zn}$ & 112 & 3 & 107 & 3 & -4.5 \\
\hline $\mathrm{Cd}$ & 0.383 & 0.014 & n.d. & n.d. & n.d. \\
\hline $\mathrm{Pb}$ & 3.97 & 0.19 & 3.75 & 0.21 & -5.5 \\
\hline \multirow{3}{*}{ Metal } & \multicolumn{2}{|c|}{ BCR-482 lichen } & \multicolumn{2}{|c|}{ AAS } & \multirow{2}{*}{ Dev. ${ }^{* *}$} \\
\hline & Concentration & \pm Uncertainty & Average & $\pm S D^{*}$ & \\
\hline & \multicolumn{4}{|c|}{$[\mathrm{mg} / \mathrm{kg}$ d.m. $]$} & {$[\%]$} \\
\hline $\mathrm{Mn}$ & 33.0 & 0.5 & 31.7 & 0.68 & -3.9 \\
\hline $\mathrm{Fe}$ & 804 & 160 & n.d. & n.d. & n.d. \\
\hline $\mathrm{Cu}$ & 7.03 & 0.19 & 6.63 & 0.17 & -5.7 \\
\hline $\mathrm{Zn}$ & 100.6 & 2.2 & 95.1 & 2.3 & -5.5 \\
\hline $\mathrm{Cd}$ & 0.56 & 0.02 & 0.53 & 0.03 & -5.3 \\
\hline $\mathrm{Pb}$ & 40.9 & 1.4 & 38.2 & 1.0 & -6.6 \\
\hline
\end{tabular}

* - standard deviation, ${ }^{* *}$ - relative difference between the measured and certified concentration $100 \% \cdot\left(c_{\mathrm{z}}-c_{\mathrm{c}}\right) / c_{\mathrm{c}}$, n.d. - not determined 
Table 2 shows heavy metals concentrations, determined in the certified reference materials as BCR-414 plankton and BCR-482 lichen, prepared by the Institute for Reference Materials and Measurements, Belgium.

In order to determine uncertainty of the measurement method, algae samples were analysed five times, maintaining the whole cycle of the research method. For the samples of algae exposed in the defined measurement spots, the value of coefficient of variation $C V_{\mathrm{sr}}$ (coefficient of variation), determined on the basis of the value of standard deviation $S D$ $\left(C V_{\text {sr. }}[\%]=1 / 3 \cdot \sum\left(S D_{i} / c_{x, s r . i}\right) \cdot 100 \%\right.$, where: $S D_{i} / c_{x, s ́ r . i}$ is a standard deviation, calculated for the i-series (number of measuring spots in other reservoirs $i=6,10$ and 4), referred to the mean value from the series $\left.\left(c_{x, s, i}\right)\right)$ is, for Palmaria palmata, within the range $11-15 \%$.

\section{Results interpretation method}

The increases of analytes concentrations in algae, indicating waters pollution, were determined on the basis of the relative accumulation factor (RAF - Relative Accumulation Factor) [23]:

$$
R A F=\frac{c_{(a, 1)}-c_{(a, 0)}}{c_{(a, 0)}}
$$

where: $c_{(a, 0)}$ - mean concentration of the analyte in algae before the exposition [mg/kg d.m.], $c_{(a, 1)}$ - mean concentration of the analyte in algae after the exposition [mg/kg d.m.].

\section{Results and discussion}

Table 3 presents $\mathrm{pH}$ and conductivity values of the water samples from the studied reservoirs, in the designed algae exposition locations (Fig. 1).

The results of measurements of physicochemical parameters of the water samples

\begin{tabular}{|c|c|c|c|}
\hline Reservoir & Parameter & $\mathbf{p H}$ & Conductivity [ $\boldsymbol{\mu S} / \mathbf{c m}]$ \\
\hline \multirow{4}{*}{ The Kielce artificial lake } & Mean & $\mathbf{7 . 8 2}$ & $\mathbf{5 2 7}$ \\
\cline { 2 - 4 } & Minimum & 7.69 & 499 \\
\cline { 2 - 4 } & Maximum & 7.89 & 624 \\
\cline { 2 - 4 } & $\pm S D$ & 0.07 & 48 \\
\hline \multirow{4}{*}{ The Chancza reservoir } & Mean & $\mathbf{8 . 3 0}$ & $\mathbf{3 4 2}$ \\
\cline { 2 - 4 } & Minimum & 7.64 & 312 \\
\cline { 2 - 4 } & Maximum & 8.68 & 476 \\
\cline { 2 - 4 } & $\pm S D$ & 0.36 & 48 \\
\hline \multirow{4}{*}{ The Sielpia reservoir } & Mean & $\mathbf{6 . 1 4}$ & $\mathbf{1 4 5}$ \\
\cline { 2 - 4 } & Minimum & 5.91 & 140 \\
\cline { 2 - 4 } & Maximum & 6.25 & 153 \\
\cline { 2 - 4 } & $\pm S D$ & 0.16 & 5.7 \\
\hline
\end{tabular}

The Sielpia reservoir waters have relatively low $\mathrm{pH}$ values $(\mathrm{pH}<7)$ and low salinity, which results in low conductivity. Considering the $\mathrm{pH}$ value one may declare that the Chancza reservoir waters contain little $\mathrm{CO}_{2}$, with domination of bicarbonates, created in consequence of binding carbon dioxide by calcium [24]. The Kielce artificial lake has the greatest salinity.

Palmaria palmata sea algae were used in order to assess the differences of concentrations of bioaccessible forms of the analysed metals. 
Table 4 presents mean concentrations of heavy metals determined in the samples Palmaria palmata, exposed in the studied reservoirs.

Concentrations of heavy metals in algae Palmaria palmata [mg/kg d.m.]

\begin{tabular}{|c|c|c|c|c|c|c|}
\hline Spot no. & Mn & $\mathbf{F e}$ & $\mathbf{C u}$ & Zn & Cd & $\mathbf{P b}$ \\
\hline \multicolumn{7}{|c|}{ The Kielce artificial lake } \\
\hline 1 & 636 & 936 & 6.43 & 40.4 & $<0.81$ & $<4.38$ \\
\hline 2 & 640 & 1021 & 8.292 & 40.4 & $<0.81$ & $<4.38$ \\
\hline 3 & 618 & 935 & 7.73 & 33.2 & $<0.81$ & $<4.38$ \\
\hline 4 & 622 & 1048 & 11.3 & 43.4 & $<0.81$ & $<4.38$ \\
\hline 5 & 623 & 1049 & 10.7 & 46.4 & $<0.81$ & $<4.38$ \\
\hline 6 & 640 & 1047 & 8.43 & 36.8 & $<0.81$ & 7.98 \\
\hline Mean & 630 & 1006 & 8.83 & 40.1 & $<0.81$ & $<4.98$ \\
\hline $\pm S D$ & 10 & 55 & 1.86 & 4.7 & - & - \\
\hline \multicolumn{7}{|c|}{ The Chancza reservoir } \\
\hline 1 & 621 & 1030 & 10.7 & 54.0 & $<0.81$ & 6.99 \\
\hline 2 & 692 & 1136 & 7.83 & 46.1 & $<0.81$ & 16.3 \\
\hline 3 & 622 & 975 & 6.34 & 35.9 & $<0.81$ & 9.38 \\
\hline 4 & 625 & 1048 & 10.4 & 40.6 & $<0.81$ & 9.68 \\
\hline 5 & 625 & 1042 & 10.9 & 40.2 & $<0.81$ & 24.1 \\
\hline 6 & 623 & 1005 & 7.55 & 30.4 & $<0.81$ & 20.8 \\
\hline 7 & 624 & 1012 & 6.16 & 33.3 & $<0.81$ & 11.6 \\
\hline 8 & 625 & 1014 & 4.84 & 34.5 & $<0.81$ & $<4.38$ \\
\hline 9 & 626 & 1054 & 9.46 & 42.6 & $<0.81$ & 20.4 \\
\hline 10 & 624 & 1045 & 6.97 & 29.7 & $<0.81$ & 19.4 \\
\hline Mean & 631 & 1036 & 8.12 & 38.7 & $<0.81$ & $<14.3$ \\
\hline $\pm S D$ & 22 & 42 & 2.12 & 7.6 & - & - \\
\hline \multicolumn{7}{|c|}{ The Sielpia reservoir } \\
\hline 1 & 634 & 1102 & 6.93 & 35.2 & $<0.81$ & 13.9 \\
\hline 2 & 632 & 1064 & 8.71 & 40.9 & $<0.81$ & 14.8 \\
\hline 3 & 634 & 1081 & 8.68 & 39.0 & $<0.81$ & 10.5 \\
\hline 4 & 631 & 1039 & 41.4 & 41.8 & $<0.81$ & 13.6 \\
\hline Mean & 633 & 1072 & 16.4 & 39.2 & $<0.81$ & 13.2 \\
\hline $\pm S D$ & 2 & 27 & 16.7 & 2.9 & - & 1.9 \\
\hline
\end{tabular}

Based on the carried out research it was stated that Palmaria palmata sea algae accumulated lead well. Lead concentrations in the majority of the algae samples after exposition were higher than the analytical determination method limit: $M Q L>4.38 \mathrm{mg} / \mathrm{kg}$ d.m. The previous laboratory tests of sea algae showed that their sorption properties, compared to fresh water algae, were less influenced by the presence of other ions in solutions, within the conductivity changes range from 200 to $1000 \mu \mathrm{S} / \mathrm{cm}$ [25]. Large $S D$ values, with reference to mean concentration values of the determined metals for each reservoir, confirm the various pollution levels of waters and signify the possibility that the determined metals originate from several different sources.

Figures 2-5 present the values of determined $R A F$ coefficients (Relation 1) for Mn, Fe, $\mathrm{Cu}, \mathrm{Zn}$ and $\mathrm{Pb}$. Increases of lead concentrations were noticed in Palmaria palmata algae exposed in the Chancza and Sielpia reservoirs and in the measuring spot 6, located in the Kielce artificial lake. 


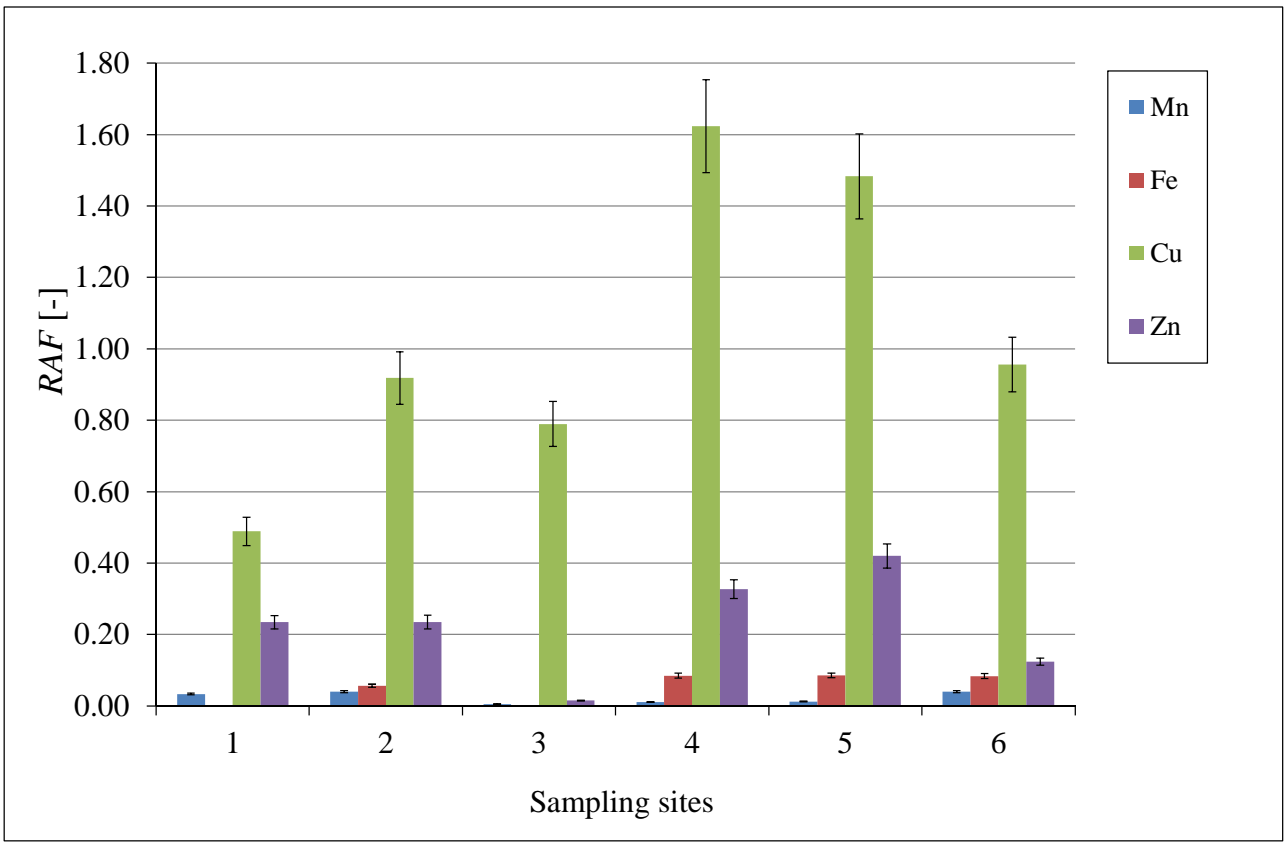

Fig. 2. Increases of heavy metals concentrations in Palmaria palmata algae exposed in the Kielce artificial lake waters

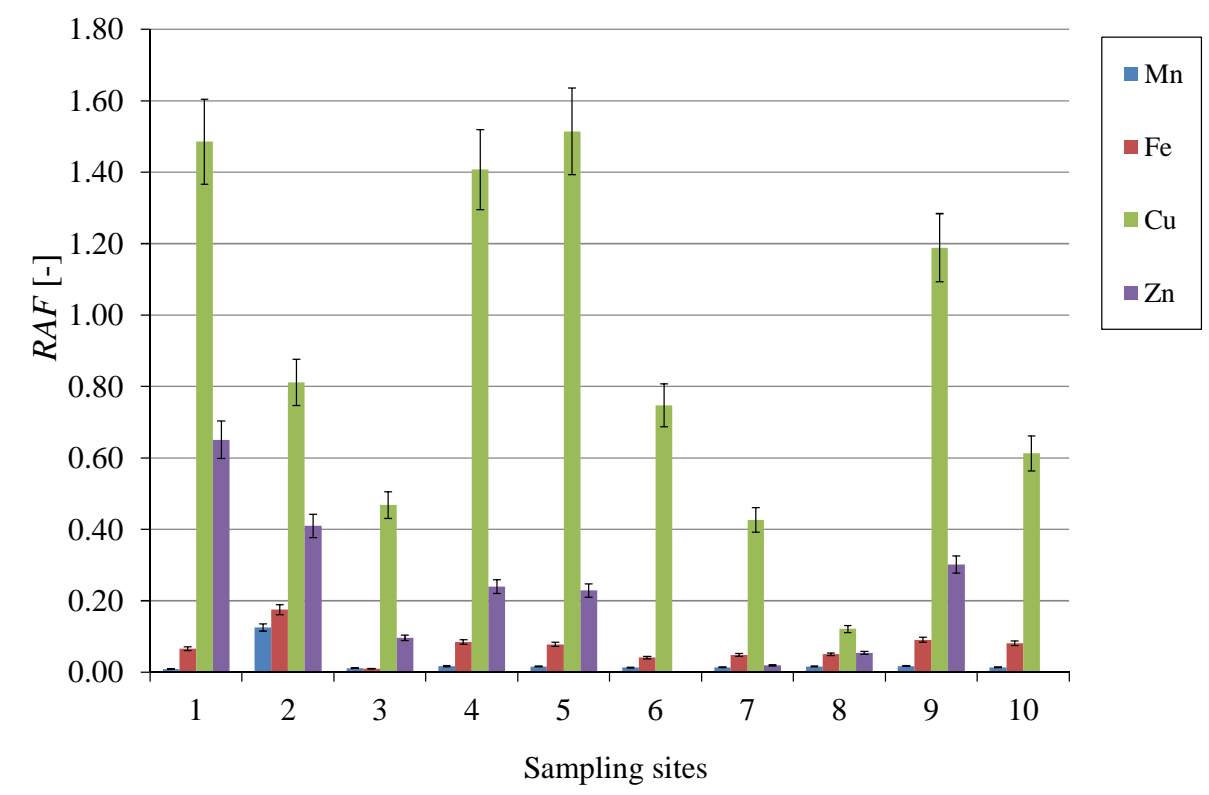

Fig. 3. Increases of heavy metals concentrations in Palmaria palmata algae exposed in the Chancza reservoir waters 


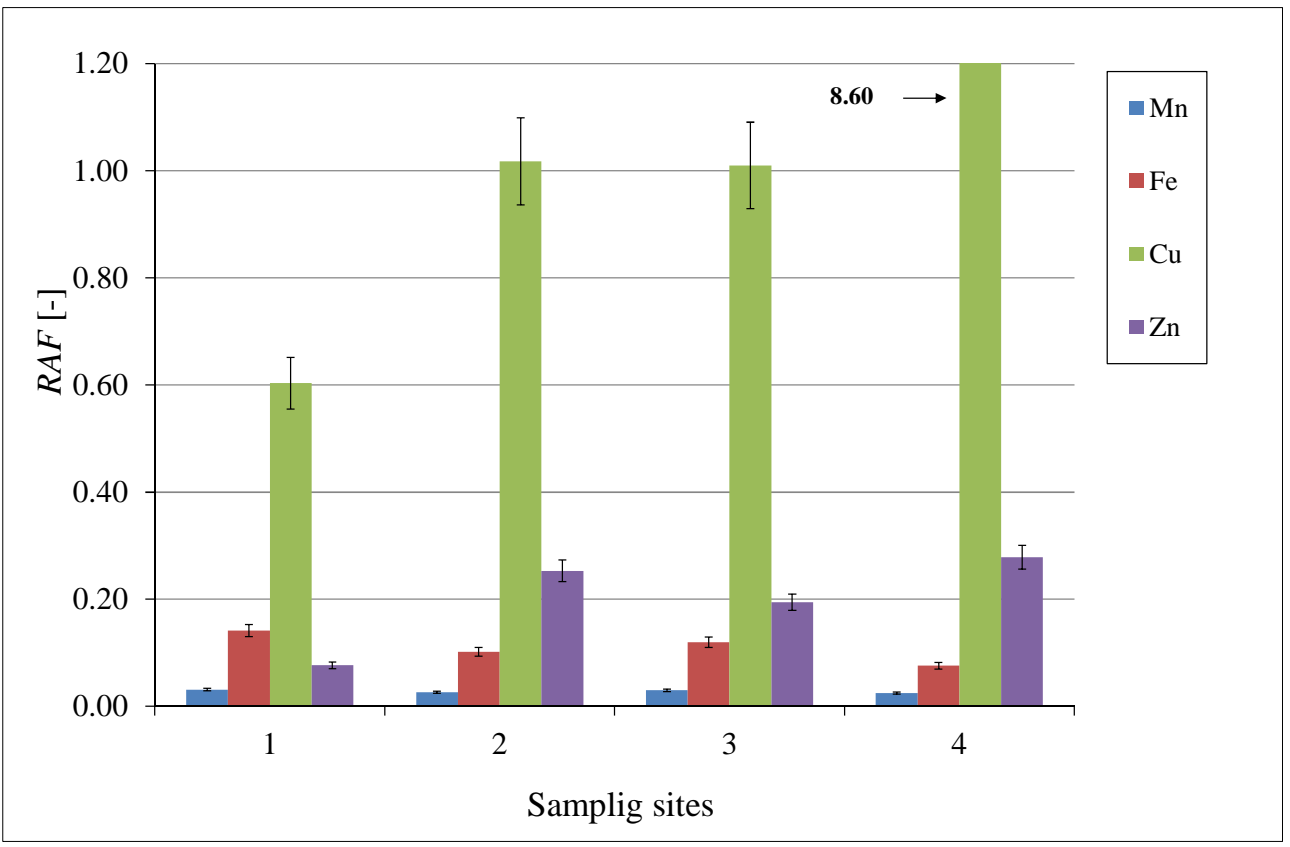

Fig. 4. Increases of heavy metals concentrations in Palmaria palmata algae exposed in the Sielpia reservoir waters

The results presented in the graphs in Figures 2-5 show a differentiated level of metals accumulation in individual reservoirs. Considering the method's unreliability, the $R A F$ values $<0.26$ are within the measurement error limits and do not signify concentration increases post-exposition. No statistically relevant differences in concentrations of $\mathrm{Mn}$ and $\mathrm{Fe}$, in the algae exposed in various spots of the Kielce artificial lake, were identified. Waters of the reservoir are polluted mainly with copper and zinc, only in spots 4 and 5 . The aggregate quarry in Wisniowka near Kielce may be the potential source of these metals. The quarry discharges mining waters to the Silnica river, which carries them on to the Kielce artificial lake. It is also significant that the lake is located close to the former copper ore mining and processing centres (Miedziana Gora).

According to the research, considerably high copper concentrations are present in the Chancza reservoirs as well as the Kielce artificial lake. The samples exposed in this reservoir had large increases of lead concentrations, particularly in exposition spots 5 and 6 and in the waters of the rivers flowing into the reservoir: Lagowica and Czarna Staszowska rivers (spots 9 and 10). This may signify that the potential lead pollution sources are the lake's tributaries and the increased lead concentrations in the samples exposed in spots 5 and 6 may result from the vicinity of bottom sediments accumulation, rich in pollutants. The spots 5 and 6 are located near the outlet of the Czarna river from the lake. The increases of zinc in the samples exposed in the lake $(R A F>0.26)$ were noted in spots 1 and 2. 


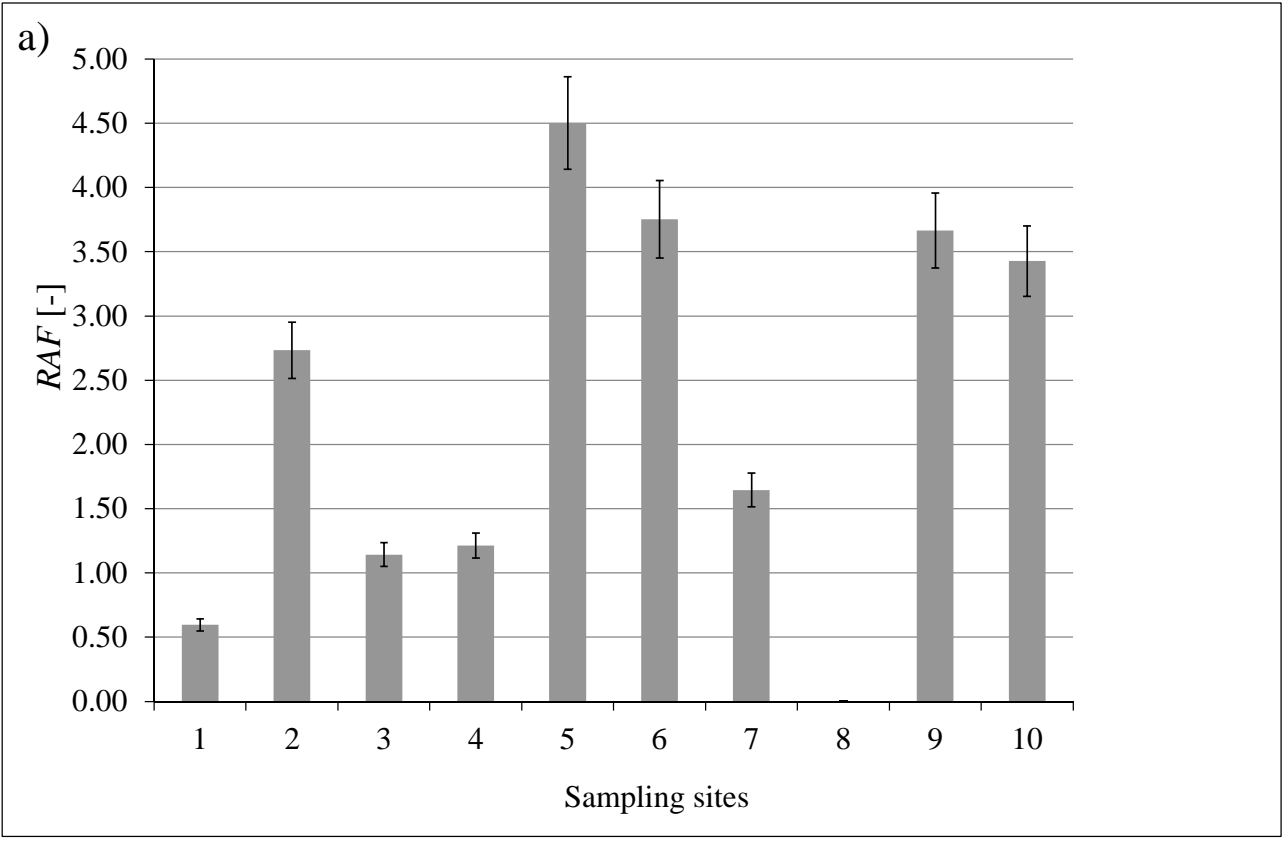

b)

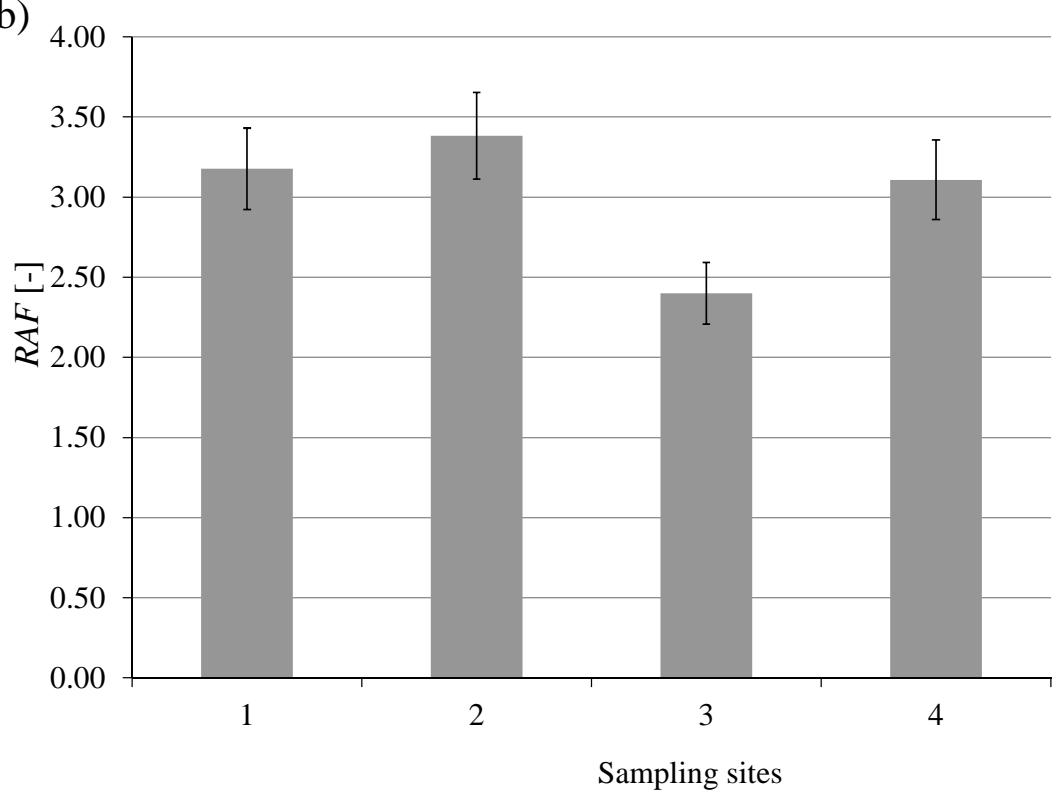

Fig. 5. Increases of lead concentrations in Palmaria palmata algae exposed in the waters of: a) Chancza, b) Sielpia 
Large increases of $\mathrm{Cu}$ and $\mathrm{Pb}$ in algae after the exposition were noted in the Sielpia and Chancza reservoirs. The Sielpia reservoir is a popular resort in Swietokrzyskie province. There are resorts and summer houses along the whole coast of the reservoir. A district road passes close to the western coast of the reservoir. However, it seems that the largest water pollution source is the bottom sediment, accumulated in large amounts during the 1997 flood. Activities aiming at revitalisation of the reservoir have been carried out recently.

\section{Summary and conclusions}

Algae are perceived as one of the major bioindicators of heavy metal pollution in surface waters biomonitoring. Analysis of heavy metals concentrations captured in algae thallus provides much information regarding the pollution introduced to water environment, allows to asses changes in environment quality and to identify the sources of pollution.

On the basis of the carried out research it was demonstrated that Palmaria palmata sea algae can be successfully used as biomonitors of water ecosystems pollution with heavy metals. The biomass of Palmaria palmata proved to be a very good biomonitor in detecting spot sources of lead pollution.

Even though algae are not homogeneous material, they can be successfully used as biosensors in detecting heavy metals pollution of surface waters.

\section{Acknowledgements}

The Project received financial assistance from the funds of the National Science Centre granted by force of the decision no. DEC-2011/03/D/NZ9/00051.

\section{References}

[1] Hédouin L, Bustamante P, Fichez R, Warnau M. The tropical brown alga Lobophora variegata as a bioindicator of mining contamination in the New Caledonia lagoon: A field transplantation study. Marine Environ Res. 2008;66:438-444. https://hal.archives-ouvertes.fr/hal-00326628/document.

[2] Rajfur M, Kłos A, Wacławek M. Algae utilization in assessment of the large Turawa Lake (Poland) pollution with heavy metals. J Environ Sci Health Part A. 2011;46:1401-1408. DOI: 10.1080/10934529.2011.606717

[3] Kumar NJI, Oommen C. Removal of heavy metals by biosorption using freshwater alga Spirogyra hyalina. J Environ Biol. 2012;33:27-31. http://imsear.li.mahidol.ac.th/bitstream/123456789/146660/1/ jeb2012v33i1p27.pdf.

[4] Christoforidis AK, Orfanidis S, Papageorgiou SK, Lazaridou AN, Favvas EP, Mitropoulos ACh. Study of $\mathrm{Cu}$ (II) removal by Cystoseira crinitophylla biomass in batch and continuous flow biosorption. Chem Eng J. 2015;277:334-340. DOI:10.1016/j.cej.2015.04.138.

[5] Hazarika J, Pakshirajan K, Sinharoy A, Syiem MB. Bioremoval of $\mathrm{Cu}(\mathrm{II}), \mathrm{Zn}$ (II), $\mathrm{Pb}$ (II) and $\mathrm{Cd}$ (II) by Nostoc muscorum isolated from a coal mining site. J Appl Phycol. 2015;27(4):1525-1534. DOI: 10.1007/s10811-014-0475-3.

[6] Hollar S, editor. A Closer at Bacteria, Algae, and Protozoa. New York: Britannica Educational Publishing; 2012.

[7] Bellinger GE, Sigee CD. Freshwater Algae. Identification and Use as Bioindicators. Chichester: John Wiley \& Sons; 2010.

[8] Barsanti L, Gualtieri P. Algae. Anatomy, Biochemistry and Biotechnology. Boca Raton, FL: Taylor \& Francis; 2006.

[9] Malea P, Kevrekidis T. Trace element patterns in marine macroalgae. Sci Total Environ. 2014;494:144-157. DOI: 10.1016/j.scitotenv.2014.06.134.

[10] Chakraborty S, Bhattacharya T, Singh G, Maity JP. Benthic macroalgae as biological indicators of heavy metal pollution in the marine environments: A biomonitoring approach for pollution assessment. Ecotoxicol Environ Safety. 2013;100:61-68. DOI: 10.1016/j.ecoenv.2013.12.003. 
[11] Kravtsova A, Milchakova N, Frontasyeva M. Elemental accumulation in the Black Sea brown algae Cystoseira studied by neutron activation analysis. Ecol Chem Eng S. 2014;21(1):9-23. DOI: 10.2478/eces-2014-0001.

[12] Brito GB, de Souza TL, Bressy FC, Moura CWN, Korn MGA. Levels and spatial distribution of trace elements in macroalgae species from the Todos os Santos Bay, Bahia, Brazil. Marine Pollut Bull. 2012;64(10):2238-2244. DOI: 10.1016/j.marpolbul.2012.06.022.

[13] Benkdad A, Laissaoui A, Tornero MV, Benmansour M, Chakir E, Garrido IM, et al. Trace metals and radionuclides in macroalgae from Moroccan coastal waters. Environ Monit Assess. 2011;182(1-4);317-324. DOI: $10.1007 / \mathrm{s} 10661-011-1878-0$.

[14] Akcali I, Kucuksezgin F. A biomonitoring study: Heavy metals in macroalgae from eastern Aegean coastal areas. Marine Pollut Bull. 2010;62(3):637-645. DOI: 10.1016/j.marpolbul.2010.12.021.

[15] Gopinath A, Muraleedharan NS, Chandramohanakumar N, Jayalakshmi KV. Statistical significance of biomonitoring of marine algae for trace metal levels in a coral environment. Environ Forensics. 2011;12(1):98-105. DOI: 10.1080/15275922.2011.547440.

[16] Schintu M, Marras B, Durante L, Meloni P, Contu A. Macroalgae and DGT as indicators of available trace metals in marine coastal waters near a lead-zinc smelter. Environ Monit Assess. 2009;167(1-4):653-661. DOI: $10.1007 / \mathrm{s} 10661-009-1081-8$.

[17] Bacsi I, Novak Z, Janoszky M, B-Beres V, Grigorszky I, Nagy SA. The sensitivity of two Monoraphidium species to zinc: their possible future role in bioremediation. Inter $\mathrm{J}$ Environ Sci Technol. 2015;12(8):2455-2466. DOI: 10.1007/s13762-014-0647-3.

[18] Vijayaraghavan K, Joshi UM. Hybrid Sargassum-sand sorbent: A novel adsorbent in packed column to treat metal-bearing wastewaters from inductively coupled plasma-optical emission spectrometry. J Environ Sci Health - Part A Toxic/Hazard Substances Environ Eng. 2013;48(13):1685-1693. DOI: 10.1080/10934529.2013.81550.

[19] Jóźwiak AM, Jóźwiak M, Kozłowski R, Rabajczyk A. The role of indicator malacofauna in pollution assessment of inland waters exposed to anthropopressure: the case of the Kielce Lake. Ecol Chem Eng S. 2010;17(4):485-495. http://tchie.uni.opole.p1/ece_s/S17_4/S4_2010.pdf.

[20] Stan środowiska w Województwie świętokrzyskim. Raport 2015. [State of the environment Świętokrzyskie province. 2015 Report]. WIOŚ. Kielce: Biblioteka Monitoringu Środowiska; 2015. http://kielce.pios.gov.pl/content/raporty/rocz/2015/raport_2015.pdf.

[21] Gruca-Rokosz R, Koszelnik P, Tomaszek JA. Ocena stanu troficznego trzech nizinnych zbiorników zaporowych Polski południowo-wschodniej [The assessment of the trophic status of the three lowland reservoirs in the southeast Poland]. Inż Ekol. 2011;(26):196-205.

[22] iCE 3000 Series AA Spectrometers Operators Manuals. Cambridge: Thermo Fisher Scientific; 2011. http://photos.labwrench.com/equipmentManuals/9291-6306.pdf.

[23] Goryainova Z, Vukovi G, Urosevic AM, Vergel K, Ostrovnaya T, Frontasyeva M, et al. Assessment of vertical element distribution in street canyons using the moss Sphagnum girgensohnii: A case study in Belgrade and Moscow cities. Atmos Pollut Res. 2016. http://dx.doi.org/10.1016/j.apr.2016.02.013. http://ac.els-cdn.com/S1309104215300787/1-s2.0-S1309104215300787-main.pdf?_tid=4246d9f8-37a811e6-8268-00000aab0f6c\&acdnat=1466510828_490188814e0b5a590dffa30f065828f7.

[24] Kawecka B, Eloranta PV. Zarys ekologii glonów wód słodkich i środowisk lądowych [An outline of fresh waters and land environment algae ecology]. Warszawa: Wyd Nauk PWN; 1994.

[25] Rajfur M, Kłos A. Sorption of heavy metals in the biomass of algae Palmaria palmata. Water Sci Technol. 2013;68(7):1543-1549. DOI: 10.2166/wst.2013.400. 